\title{
Mechanical Properties of Endospermum diadenum sp. Grown in Sarawak
}

\author{
Nur Syahina Yahya ${ }^{1}$, Gaddafi Ismaili ${ }^{2}$ \\ Department of Civil Engineering, Faculty of Engineering, Universiti Malaysia Sarawak, Kota Samarahan, \\ Sarawak, Malaysia ${ }^{1-2}$
}

\begin{abstract}
Timber is a renewable resource and preferred as building and construction material due to physical, mechanical, and has an aesthetically performance. However, timber varies due to its own property and proposes. The quality of the timber has a strong influence on the quality and value of timber products. Therefore, this study will be conducted to learn about mechanical strength properties of Terbulan (Endospermum diadenum sp.) fast-growing timber according to BS 373: 1957 Methods of Testing Small Clear Specimens of Timber. Instead of strength property, this study will be determined the suitable utilization of Terbulan timber for the construction industry. The test will be conducted on both conditions which are green and air-dry condition. Generally, Terbulan species is a fast-growing timber in Sarawak. From the point of view, the strength properties parameters such as basic density, modulus of rupture (MOR), modulus of elasticity (MOE) and compressive strength of Terbulan timber will be reviewed to determine the effectiveness of the species in the construction field. As a result of the analysis, it is found that Terbulan timber at the air-dry condition for MOR, MOE and compression parallel to grain reported with $84.17 \mathrm{~N} / \mathrm{mm}^{2}, 10217.79 \mathrm{~N} / \mathrm{mm}^{2}$ and $28.94 \mathrm{~N} / \mathrm{mm}^{2}$ respectively. Terbulan is categorized in light hardwood timber and conclusion, related products are confined at the beginning it is a steel and concrete replacement that is mostly used in structure such as light construction, furniture and joinery.
\end{abstract}

Keywords: mechanical properties, fast-grown, strength properties, light hardwood.

\section{INTRODUCTION}

Wood is a renewable resource and one of the most compression parallel to grain test at Sarawak Forestry fascinating materials because of its complex structure and laboratory. Furthermore, the study will determine the wide application on earth. Solid wood is a preferred strength of Terbulan timber for construction industry. The building and construction material due to its physical, scope of this study also will further discuss the factors mechanical, and very aesthetically pleasing performances. affect the mechanical properties of this species of timber.

However, wood has some drawbacks: its physical and chemical properties readily are changed through environment factors such as light, water, temperature, and biological organisms, which are the main limits for its outdoors and indoors application (Yalinkilic et al. 1999; Caho et al. 2003; Brelid et al. 2000; Deka et al. 2002; Islam et al. 2011). Apart from that, timber is a superior material for building due to its aesthetic, pleasant, warm and friendly effects as well as other advantages, (MTIB, 2009). Moreover, according to Kalinovsky (2010), it stated that timber has the amazing appearance, durability and performance values. It is flexible, reliable and fast to work with. Timber species has its own property and purpose. Their properties vary to each other mostly in their appearance and usage.

\section{BACKGROUND}

According to Alik (2002), modern technology has made possible for the development of improved grading practices and improved engineered timber products. Destructive test evaluation is one of the techniques that may be useful in grading structural materials, (Alik, 2002). The procedure of destructive testing was adopted according to the British Standard BS 373: 1957, Methods of Testing Small Clear Specimens of Timber. In order to obtain the mechanical properties of this timber, the tests that to be conducted are static bending test and

\section{METHODOLOGY}

A. Preparation of Material

The samples of Terbulan (Endospermum diadenum sp.) are collected from the forest that planted within Unimas campus area. There are $15 \operatorname{logs}$ with the diameter 15-20 $\mathrm{cm}$ and 5-7 $\mathrm{m}$ long. The ages of the trees are range between $3-5$ years old. The samples are prepared for two conditions, which are green and air-dry conditions. The drying process is taking almost 2 months to dry. A total of 250 Terbulan samples were used for the tests. All the preparation for small clear specimens is according to Japanese Standard, JIS 2010-1994. The tests involve are static bending test and compression parallel to grain by using the destructive test (DT) method is determined at Sarawak Forestry Corporation. The procedures of the test adopted according to the British Standard BS 373: 1957, Methods of Testing Small Clear Specimens of Timber.

\section{B. Laboratory Work}

The specimens are tested by using Universal Testing Machine (UTM) in order to determine the Modulus of Rupture (MOR), Modulus of Elasticity (MOE), maximum loads and maximum compressive strength of specimens.

1. Static Bending Test

The static bending is carried out by the three point bending method. The dimension of a specimen is $20 \mathrm{~mm}$ x $20 \mathrm{~mm}$ 
x $300 \mathrm{~mm}$. Total specimens for the test are hundred (100) specimens for both green and air-dry conditions. Moreover, a constant loading speed is $6.0 \mathrm{~mm} \mathrm{~min}^{-1}$. Modulus of rupture (MOR) and Modulus of elasticity (MOE) in $\mathrm{N} / \mathrm{mm}^{2}$ are calculated by using the following formulae:

$\mathrm{MOR}=\frac{3 \mathrm{FL}}{2 \mathrm{WT}^{2}}$ Eqn. 1

Where, F: maximum load, $\mathrm{N}$

L: span, mm

$\mathrm{W}$ : width, mm

$\mathrm{T}$ : depth, mm

$\mathrm{MOE}=\frac{\mathrm{L}^{3} \Delta \mathrm{F}}{4 \mathrm{WT}^{3} \Delta \mathrm{l}}$ Eqn. 2

Where, L: span, mm

$\Delta \mathrm{F} / \Delta \mathrm{l}$ : slope of graph, $\mathrm{N} / \mathrm{mm}^{2}$

$\mathrm{W}$ : width, $\mathrm{mm}$

$\mathrm{T}$ : depth, mm

\section{Compression Parallel to Grain Test}

The dimensions of the test piece are $20 \mathrm{~mm} \times 20 \mathrm{~mm} \times 60$ $\mathrm{mm}$. The load applied parallel to the grain. The total specimens for the test are 150 specimens for both green and air-dry conditions. To ensure accuracy of a result, the ends of the rectangular test piece should be smooth and normal to the axis of force, (Tan et. al, 2010). A constant loading speed is $0.6 \mathrm{~mm} \mathrm{~min}^{-1}$. Compressive strength at maximum load in $\mathrm{N} / \mathrm{mm}^{2}$ is calculated by using the formula:

Compressive strength $=\frac{\mathrm{F}}{\mathrm{A}} \ldots \ldots \ldots \ldots$ Eqn. 3

Where, F: maximum load, $\mathrm{N}$

\section{A: cross-sectional area}

\section{RESULT AND DISCUSSION}

\section{A. Static Bending}

All the results of testing are carried out at Sarawak Forestry Laboratory is analysed and the mean value is obtained for each of testing. The study also includes the test on the physical characteristic of timber which is moisture content and basic density.

The green moisture content of the timber is variable within a tree and species (Gaddafi, 2015; Panshin et. al 1980) and the ability of species that can preserve certain percentages of moisture contents is directly depending on its timber cells (Gaddafi, 2015).

From the mean result, the result is verified by the researcher finding as the timber reached $12 \%$ moisture content is considered dry. Frazier (2008) stated that, this Terbulan species is considered dry as it reached $12 \%$ of moisture content. Besides that, from the result, strength properties such as MOE, MOR and compressive strength are increased with decreasing of the moisture content.

The strength and stability of timber are greatly influenced by its moisture content (Gaddafi, 2015). It is also proven from the research done by Frazier (2008), this species has been high bending strength in the air-dry condition compared to that of green condition.
TABLE 1 THE AVERAGE VALUE STRENGTH PROPERTIES OF EACH OF TREE

\begin{tabular}{|c|c|c|c|c|c|c|}
\hline \multirow{2}{*}{$\begin{array}{c}\text { Strength } \\
\text { Properties }\end{array}$} & \multicolumn{3}{|c|}{ Green } & \multicolumn{3}{|c|}{ Air-dry } \\
\hline & $\begin{array}{c}\text { TR } \\
\text { 001 } \\
\end{array}$ & $\begin{array}{c}\text { TR0 } \\
\text { 02 }\end{array}$ & $\begin{array}{c}\text { TR0 } \\
\text { 03 }\end{array}$ & $\begin{array}{l}\text { TR } \\
004 \\
\end{array}$ & $\begin{array}{c}\text { TR } \\
005 \\
\end{array}$ & $\begin{array}{c}\text { TR0 } \\
06\end{array}$ \\
\hline $\begin{array}{l}\text { Maximum } \\
\text { Load, Static } \\
\text { Bending } \\
\text { (N) }\end{array}$ & $\begin{array}{c}887 . \\
88\end{array}$ & $\begin{array}{l}102 \\
4.72\end{array}$ & $\begin{array}{c}1077 \\
.52\end{array}$ & $\begin{array}{l}154 \\
9.30\end{array}$ & $\begin{array}{l}159 \\
8.23\end{array}$ & $\begin{array}{c}1662 . \\
41\end{array}$ \\
\hline $\begin{array}{c}\text { Maximum } \\
\text { load, } \\
\text { Compressio } \\
\text { n Parallel to } \\
\text { Grain }(\mathrm{N})\end{array}$ & $\begin{array}{l}969 \\
4.40\end{array}$ & $\begin{array}{l}101 \\
40.5 \\
8\end{array}$ & $\begin{array}{l}1055 \\
7.60\end{array}$ & $\begin{array}{c}119 \\
67.2 \\
0\end{array}$ & $\begin{array}{c}121 \\
52.3 \\
0\end{array}$ & $\begin{array}{l}1284 \\
9.22\end{array}$ \\
\hline $\begin{array}{c}\text { MOR } \\
\left(\mathrm{N} / \mathrm{mm}^{2}\right) \\
\end{array}$ & $\begin{array}{c}46.6 \\
1 \\
\end{array}$ & $\begin{array}{c}53.8 \\
0 \\
\end{array}$ & $\begin{array}{c}56.5 \\
7 \\
\end{array}$ & $\begin{array}{c}81.3 \\
4 \\
\end{array}$ & $\begin{array}{c}83.9 \\
1 \\
\end{array}$ & 87.28 \\
\hline $\begin{array}{c}\mathrm{MOE} \\
\left(\mathrm{N} / \mathrm{mm}^{2}\right)\end{array}$ & $\begin{array}{l}639 \\
3.75 \\
\end{array}$ & $\begin{array}{l}749 \\
6.38 \\
\end{array}$ & $\begin{array}{c}8672 \\
.15\end{array}$ & $\begin{array}{l}981 \\
8.00 \\
\end{array}$ & $\begin{array}{l}984 \\
7.00 \\
\end{array}$ & $\begin{array}{l}1099 \\
9.00 \\
\end{array}$ \\
\hline $\begin{array}{l}\text { Compressiv } \\
\text { e strength } \\
\left(\mathrm{N} / \mathrm{mm}^{2}\right) \\
\end{array}$ & $\begin{array}{c}22.7 \\
7 \\
\end{array}$ & $\begin{array}{c}24.7 \\
4 \\
\end{array}$ & $\begin{array}{c}25.2 \\
0 \\
\end{array}$ & $\begin{array}{c}27.9 \\
3 \\
\end{array}$ & $\begin{array}{c}29.2 \\
9 \\
\end{array}$ & 29.61 \\
\hline $\begin{array}{c}\text { Moisture } \\
\text { Content }(\%)\end{array}$ & $\begin{array}{c}56.6 \\
2 \\
\end{array}$ & $\begin{array}{c}50.7 \\
8 \\
\end{array}$ & $\begin{array}{c}47.0 \\
4 \\
\end{array}$ & $\begin{array}{c}12.8 \\
5 \\
\end{array}$ & $\begin{array}{c}11.4 \\
8 \\
\end{array}$ & 11.00 \\
\hline $\begin{array}{c}\text { Basic } \\
\text { density } \\
\left(\mathrm{g} / \mathrm{cm}^{3}\right)\end{array}$ & 0.51 & 0.57 & 0.61 & 0.44 & 0.44 & 0.47 \\
\hline
\end{tabular}

The research done by Alik \& Kuroda (1996), shows that the basic density is the strong indicator correlate to the mechanical strength properties. All the samples are combined in getting the accurate result, thus present the precise mechanical strength values.

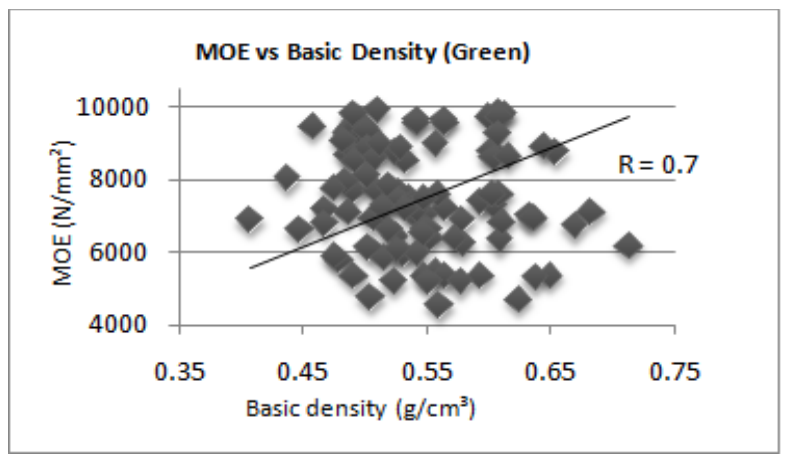

Figure1. MOE vs Basic Density (Green)

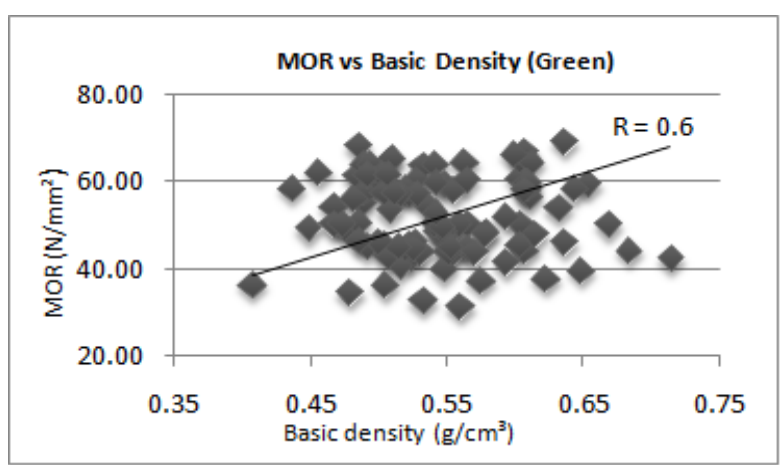

Figure2. MOR vs Basic Density (Green)

Based on Figure 1 and Figure 2, these are representing the MOE and MOR against basic density for green condition. The three trees are combined in order getting the mean 
value for the respective MOE and MOR. The black marking indicates the number of samples that had been tested. The conclusion that can be made from the both graphs is MOE and MOR is directly proportional to the basic density.

As the graph plotted, the regression, $\mathrm{R}$ for linear proportion should be approaching one (1). From the graphs, the $\mathrm{R}$ values for MOR and MOR are $0.663 \approx 0.7$ and $0.648 \approx 0.6$ respectively. Thus, it can be concluded that, as the $\mathrm{R}$ values are approaching one (1), thus the result had significant correlation. In general, MOR and MOE are derived from the bending strength test. Therefore, at high maximum loading, it gives the high MOE and MOR values. Extension from that, Table 2 represent the mean of MOE, MOR, maximum load and basic density at green condition.

\section{TABLE 2 THE MEAN OF MOR, MOE, MAXIMUM LOAD AND BASIC DENSITY AT GREEN CONDITION}

\begin{tabular}{|c|c|}
\hline Strength properties & Mean value \\
\hline $\begin{array}{c}\text { Modulus of Rupture, MOR } \\
\left(\mathrm{N} / \mathrm{mm}^{2}\right)\end{array}$ & 54.34 \\
\hline $\begin{array}{c}\text { Modulus of Elasticity, MOE } \\
\left(\mathrm{N} / \mathrm{mm}^{2}\right)\end{array}$ & 7521.50 \\
\hline Maximum load $(\mathrm{N})$ & 996.98 \\
\hline Basic density $\left(\mathrm{g} / \mathrm{cm}^{3}\right)$ & 0.54 \\
\hline
\end{tabular}

From the result obtained, at green condition, the MOR value is $54.34 \mathrm{~N} / \mathrm{mm}^{2}$ compared to the MOR value (39 $\mathrm{N} / \mathrm{mm}^{2}$ ) stated from previous research is slightly differed. However, the MOE value is almost close to the previous research that obtained $7600 \mathrm{~N} / \mathrm{mm}^{2}$. It is proven by Masseat et. al, (2010), Terbulan species at $60 \%$ moisture content showed that the modulus of rupture (MOR) is 39 $\mathrm{N} / \mathrm{mm}^{2}$ and modulus of elasticity (MOE) is $8500 \mathrm{~N} / \mathrm{mm}^{2}$.

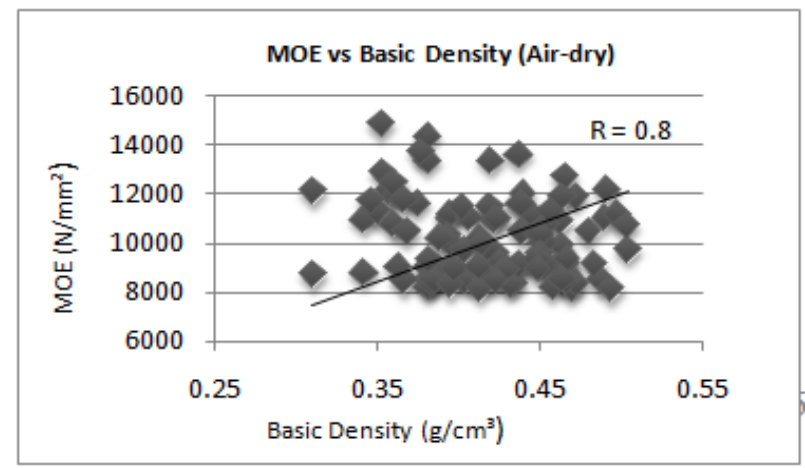

Figure3. MOE vs Basic Density (Air-dry)

Based on the graph presented in Figure 3 and Figure 4, the black marking indicates the specimen samples at the airdry condition. From the graph, it can be concluded that, the MOE and MOR values are directly proportional to the basic density at the air-dry condition. Apart from that, the regression, $\mathrm{R}$ values are shown it close to one (1). The $\mathrm{R}$ values MOE and MOR are $0.836 \approx 0.8$ and $0.754 \approx 0.7$ respectively. The same results were observed in green condition, where $\mathrm{R}$ value is close to one (1). Furthermore, Table 3 represents the mean of MOR, MOE, maximum load and basic density at air-dry condition.

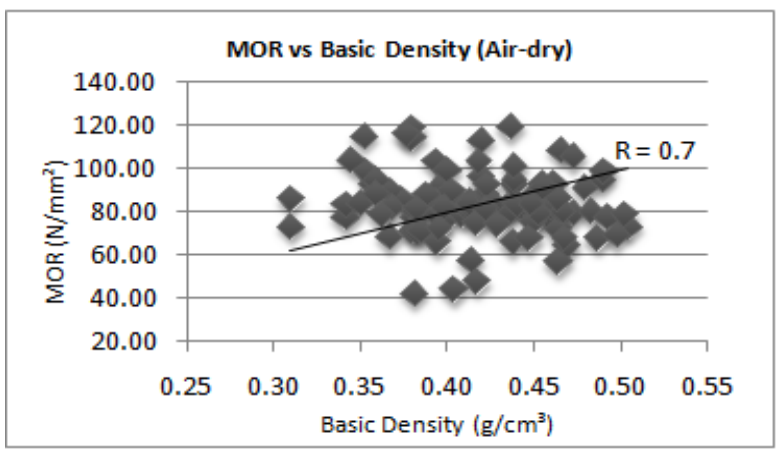

Figure4. MOR vs Basic Density (Air-dry)

\section{TABLE 3 THE MEAN OF MOR, MOE, MAXIMUM LOAD AND BASIC DENSITY AT AIR-DRY CONDITION}

\begin{tabular}{|c|c|}
\hline Strength properties & Mean value \\
\hline $\begin{array}{c}\text { Modulus of Rupture, } \\
\text { MOR (N/mm²) }\end{array}$ & 84.17 \\
\hline $\begin{array}{c}\text { Modulus of Elasticity, } \\
\text { MOE (N/mm })\end{array}$ & 10217.79 \\
\hline Maximum load $(\mathrm{N})$ & 1603.27 \\
\hline Basic density $\left(\mathrm{g} / \mathrm{cm}^{3}\right)$ & 0.42 \\
\hline
\end{tabular}

From the observation, the MOR and MOE values are just slightly differed from the previous research. It is stated that the values of MOR and MOE are $80.57 \mathrm{~N} / \mathrm{mm}^{2}$ and $10678 \mathrm{~N} / \mathrm{mm}^{2}$ respectively (Maaseat et. al, 2010). In comparison between basic density and modulus of elasticity at both conditions, it is showed that with lower basic density will increase the modulus of elasticity. It was proved by Gaddafi (2015); Sven et. al (2003), that the relationship between bending strength and modulus of elasticity can be affected by the way in which the timber is dried. In was report, greater the green density of timber, the lower basic density (Gaddafi, 2015; Walker, 1993).

\section{B. Compression Parallel to Grain}

Figure 5 and Figure 6 representing the compressive strength against green and air-dry conditions respectively. From the graphs plotted, it is show that compressive strength is directly proportional to the basic density for both green and air-dry conditions. The result obtained highly proved that the timber tested in compression and loaded parallel to grain stronger than when loaded perpendicular to the grain (Gaddafi, 2015).

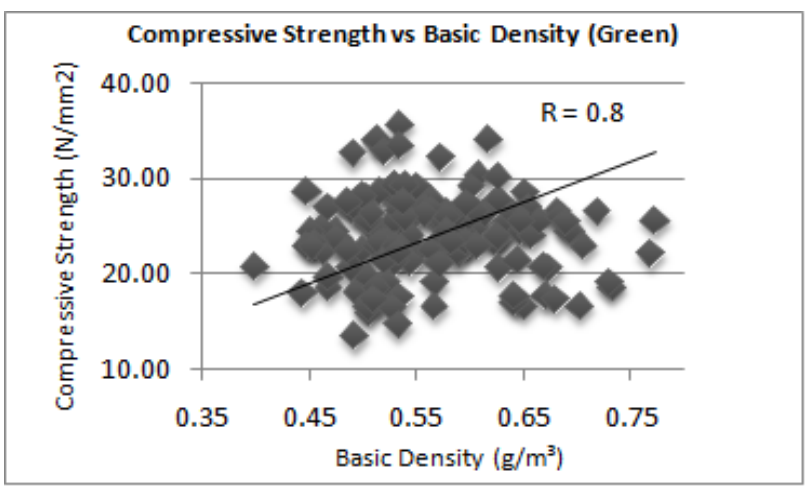

Figure5. Compressive Strength vs Basic Density (Green) 
Compressive Strength vs Basic Density (Air-dry)

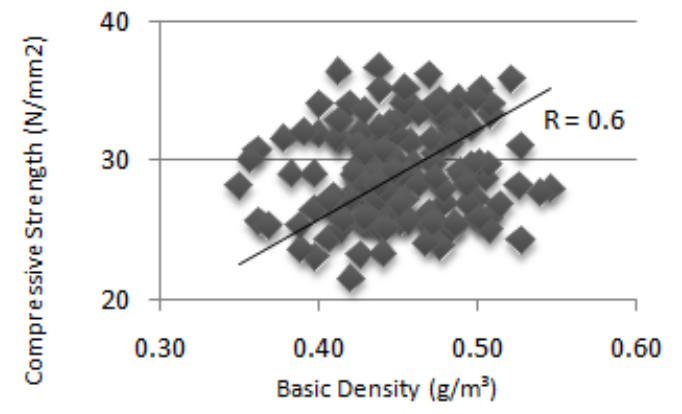

Figure6. Compressive Strength vs Basic Density (Air-dry)

The regression, $\mathrm{R}$ values for green and air-dry conditions are $0.775 \approx 0.8$ and $0.616 \approx 0.6$ respectively. The $\mathrm{R}$ values are approaching one (1), thus the data obtained are reliable. In addition, for further details, Table 4 of the mean of compressive strength, maximum load and basic density is presented.

\section{TABLE 4THE MEAN OF COMPRESSIVE STRENGTH, MAXIMUM LOAD AND BASIC DENSITY}

\begin{tabular}{|c|c|c|}
\hline \multirow{2}{*}{$\begin{array}{c}\text { Strength } \\
\text { properties }\end{array}$} & \multicolumn{2}{|c|}{ Mean value } \\
\cline { 2 - 3 } & Green & Air-dry \\
\hline $\begin{array}{c}\text { Compressive } \\
\text { strength, }\left(\mathrm{N} / \mathrm{mm}^{2}\right)\end{array}$ & 24.23 & 28.94 \\
\hline $\begin{array}{c}\text { Maximum load, } \\
(\mathrm{N})\end{array}$ & 10130.86 & 12322.91 \\
\hline $\begin{array}{c}\text { Basic density } \\
\left(\mathrm{g} / \mathrm{cm}^{3}\right)\end{array}$ & 0.56 & 0.45 \\
\hline
\end{tabular}

Based on the mean values of compressive strength for green and air-dry conditions, the differences compared to the previous study are not too far. The previous research is done at green condition with $60 \%$ of moisture content and air-dry condition $12 \%$ of moisture content. Meanwhile, from this study, the moisture content for green and air-dry condition is $51.48 \%$ and $11.77 \%$ respectively. Thus, the results obtained for compressive strength is just slightly differed from the previous study that done by Tropix (2012). The previous study stated that the compressive strengths for green and air-dry condition are $40 \mathrm{~N} / \mathrm{mm}^{2}$. However, for air-dry condition, the result obtained is 28.94 $\mathrm{N} / \mathrm{mm}^{2}$ and compressive strength done by Tropix (2012) is $40 \mathrm{~N} / \mathrm{mm}^{2}$, so that, the result obtained is acceptable.

For overall testings, in comparison of mean value of strength properties between green and air-dry conditions, it shows that air-dry condition gives a higher value than that of green condition. This happens due to decreasing of moisture content as the low amount of moisture exists in air-dry sample specimens. The increment if strength with reduction in moisture is because of shortening and consequently and strengthening of hydrogen bonds linking together the micro fibrils (Gaddafi et. al, 2011; Desch, 1981). It is proven by the previous research by Frazier (2008), it is stated that strength getting increase as reducing the moisture content.

The differences of the result might be caused by a few factors instead of moisture content. The factors listed are due to basic density, knots, temperature and humidity. In term of basic density, the correlation with mechanical strength is when moisture content is decrease, hence, basic density also reduces, thus, can cause mechanical strength to rise up. Moreover, density is also affects the mechanical strength of timber. It is correlate when density is high, it means the timber is stronger. The heaviest species, i.e. those with most wood substance, have thick cell walls and small cell cavities. They also have the highest densities and consequently are the strongest species, (McKenzie, 2000).

Apart from that, effect of knots also caused the variety the mechanical strength value. It is shows the reduction in strength in presence of knots on the specimen. Knots bring negative effects, (Smith, Landis, \& Gong, 2003). Research by Gaddafi et. al (2011); Zink (1993) also stated that the strength and stiffness of timber members containing knots is reduced due to the disruption of the grain in the region of the knot. Besides that, temperature and humidity also affected. Its occur when temperature is high, so it will reduce the humidity and moisture content will rises, thus, mechanical strength will increases.

C. The End-user Application

The results are obtained from this study have been approved with the previous research. Thus, according to Masseat et. al (2010) and Tropix, (2012), it stated the common uses of the Terbulan timber as shown in Table 5 and Table 6 respectively.

TABLE 5 THE COMMON USAGE OF TERBULAN

TIMBER BASED ON MASSEAT ET. AL, (2010)

\begin{tabular}{|c|c|c|c|}
\hline \multirow[t]{2}{*}{$\begin{array}{l}\text { Mechanical } \\
\text { Properties }\end{array}$} & $\begin{array}{c}\text { Present } \\
\text { Research }\end{array}$ & $\begin{array}{c}\text { Masseat } \\
\text { et. Al } \\
(2010) \\
\end{array}$ & $\begin{array}{l}\text { Common } \\
\text { Usage }\end{array}$ \\
\hline & \multicolumn{2}{|c|}{ Air-dry Condition } & \\
\hline $\begin{array}{c}\mathrm{MOR} \\
\left(\mathrm{N} / \mathrm{mm}^{2}\right)\end{array}$ & 84.17 & 80.57 & $\begin{array}{c}\text { Furniture, } \\
\text { components, } \\
\text { joinery, } \\
\text { dining, } \\
\text { room } \\
\text { furniture } \\
\end{array}$ \\
\hline $\begin{array}{c}\mathrm{MOE} \\
\left(\mathrm{N} / \mathrm{mm}^{2}\right)\end{array}$ & 10217.79 & 10678.00 & $\begin{array}{l}\text { Bent parts, } \\
\text { dining, stair } \\
\text { works, room } \\
\text { furniture, } \\
\text { utility } \\
\text { furniture }\end{array}$ \\
\hline
\end{tabular}

TABLE 6 THE COMMON USAGE OF TERBULAN TIMBER BASED ON TROPIX (2012)

\begin{tabular}{|c|c|c|c|}
\hline $\begin{array}{c}\text { Mechanical } \\
\text { Properties }\end{array}$ & $\begin{array}{c}\text { Present } \\
\text { Research }\end{array}$ & $\begin{array}{c}\text { Tropix, } \\
\text { (2012) }\end{array}$ & \multirow{2}{*}{$\begin{array}{c}\text { Common } \\
\text { Usage }\end{array}$} \\
\cline { 2 - 3 } & \multicolumn{2}{|c|}{ Air-dry Condition } & \\
\hline Compression & 28.94 & 40.00 & $\begin{array}{c}\text { Light } \\
\text { Parallel to } \\
\text { Grain }\end{array}$ \\
$\left(\mathrm{N} / \mathrm{mm}^{2}\right)$ & & & $\begin{array}{c}\text { construction, } \\
\text { stairworks, } \\
\end{array}$ \\
& & & stools, \\
& & & stringers, \\
& & & utility \\
& & & furniture \\
\hline
\end{tabular}




\section{CONCLUSION}

Mechanical properties of Endospermum diadenum sp. are evaluated by using Destructive Test (DT) methods. The mechanical properties involved are static bending strength and compressive strength parallel to grain. Based on the experimented data and graph that had been analysed, the following conclusions can be made:

- Mechanical properties values are established by relationship between MOE, MOR and compressive strength with basic density. The increments of those values are depended on reduction in basic density and the behaviour of basic density is influenced by percentage of moisture content.

- The results obtained are affected by various factors. The factors involved are percentage of moisture content, basic density, temperature, humidity and knots.

- In industry, the strength of Endospermum diadenum sp. is suitable for small manufacturing of interior-room furniture, light constructions, rustic furniture and utility furniture.

\section{ACKNOWLEDGEMENTS}

The authors would like to gratefully acknowledge everyone involve in this research works, especially to AFSID, Sarawak Forestry and Faculty of Resources Science and Technology. Thank you all for your advice and support.

\section{REFERENCES}

[1]. Ahmad, Z. (2011). Timber Performance in Construction. Seminar Timber in Construction.

[2]. America, \& William, M. (1994). Endospermum Benth. In Lemmens, R. H. M. J. \& Soerianegara, I.(Eds); Plant Resources of South-East Asia No 5(1). Timber trees; Major Commercial timbers. Prosea Foundation, Bogor, Indonesia., 193 - 200.

[3]. Aydin, S., Yardimci, M. Y., \& Ramyar, K. (2006). Mechanical Properties of Four Timber Specied Commonly Used in Turkey. Turkish J. Eng. Env. Sci. 31 (2007), 19-27.

[4]. Beardmore, R. (2009). Timber Properties Retrieved $12^{\text {th }}$ October, 2012, from http://www.roymech.co.uk

[5]. MTIB (2009). National Conference on Timber EngineeringChalengges Retrieved $14^{\text {th }}$ October, 2012, from http://www.mtib.gov.my

[6]. Standards, B. (373: 1957). Methods of Testing Small Clear Specimens of Timber.

[7]. Alik, D., \& Kuroda, N. (1996). The Relationship Between Basic Density and Mechanical Strength Properties of Some Sarawak Timbers. Forest Product Seminar 1996, Kuching, Sarawak.

[8]. Alik, D. (2002). Evaluation of NDT Methods to Predict Mechanical Strength Properties of Full Size Structural Timbers. Forest Product Seminar 2002,Timber Research and Technical Training Centre, Forest Department Sarawak, 138.

[9]. Frazier, S. (2008). Strength Property for Endospermum spp. Retrieved $12^{\text {th }} \quad$ October, 2012, from http://www.woodworkerssource.com/show_numerical.php?wood= Endospermum $\% 20 \mathrm{spp}$

[10]. Gaddafi, I. (2012). Engineering Properties of Selected Sarawak Fast Growing Indigenous Timber Species. PhD Thesis, Universiti Sains Malaysia.

[11]. Gaddafi, I. (2015). Engineering Properties of Fast Growing Indigenous Timber in Sarawak Compare to Acacia Mangium: Aras. International Journal of Innovative Science and Modern Engineering (IJIMSE), ISSN: 2319-6386, Vol. 3 Issue 2, January 2015.
[12]. Gaddafi, I., Bakar, B. H. A., \& Rahim, K. K. A. (2011). Evaluation of Acacia Mangium in Structural Size at Green Condition. UNIMAS E-Journal of Civil Engineering Vol 2 (2) 2011.

[13]. Globinmed. (2010). Endospermum Diadenum (Miq.) Airy Shaw Retrieved $3^{\text {rd }}$ October, 2012, from http://www.globinmed.com

[14]. Islam, M. S., Hamdan, S., Rahman, M. R., Jusoh, I., Ahmed, A. S., \& Idrus, M. a. (2011). Dynamic Young's Modulus, Morphological and Thermal Stability of 5 Tropical Light Hardwoods Modified by Benzene Diazonium Salt Treatment. Bio Resources 6(1), 737-750.

[15]. J. Bodig \& B.A. Jayne, Mechanics of Wood and Wood Composites, Krieger Publishing, 1993. pp. vii, 5, 291, 297, 299, 305.

[16]. Japanese Industrial Standard, 1994, Methods of test for woods. JIS Z 2010-1994, Japanese Standards Association, Tokyo, Japan

[17]. Kalinovsky, D. (2010). Construction and PEFC-Certified Timber Retrieved $3^{\text {rd }}$ October, 2012, from http://www.pefc.co.uk

[18]. Masseat, K., Mahat, M. N., Khaidzir, M. O. M., Salleh, A. H., Musa, M. H., \& Awang, K. (2010). Solid Wood and Veneer Study of 12-Year Old Sesenduk Clone. Forest Research Institute Malaysia. GPP-TM-1208-01/41310402001, Modern Applied Science Vol. 4, No. 7; July 2010.

[19]. McKenzie, W. M. C. (2000). Design of Structural Timber: Macmillan Press Ltd.

[20]. Smith, I., Landis, E., \& Gong, M. (2003). Fracture and Fatigue in Wood: John Wiley \& Sons Ltd, The Atrium,Southern Gate, Chichester.West Sussex PO19 8SQ, England.

[21]. Tan, Y. E., Lim, N. P. T., Gan, K. S., Wong, T. C., Lim, S. C., \& Thilagawathy, M. (2010). Testing Methods for Plantation Grown Tropical Timbers: Forest Research Institute Malaysia.

[22]. Tropix. (2012). Sesenduk (Family: Euphorbiaceae) Retrieved 16th November, 2015, from http://tropix.cirad.fr/FichiersComplementaires/EN/Asia/SESENDO K.pdf 